\title{
Effect of Alpha-Naphthalene Acetic Acid [NAA] on Growth, Flowering and Yield of Vinca rosea cv. Catharanthus caramel
}

\author{
Pooja Pahare $^{1^{*}}$ and J.N. Das ${ }^{2}$ \\ Department of floriculture and landscaping, Odisha University of Agriculture and \\ Technology, Bhubaneswar 751003, India \\ *Corresponding author
}

Ke y w o r d s
NAA vinca rosea,
(cv. Catharanthus
caramel) growth
and yield

\section{A B S T R A C T}

A field trial was conducted in the Department of Floriculture and Landscaping, Orissa University of Agriculture and Technology, Bhubaneswar to find out the effect of plant growth regulators at three concentrations viz, NAA $(25,50 \&$ $100 \mathrm{ppm}$ ) on growth and flowering of Vinca rosea (Catharanthus roseus L.) during May 2015 to September 2015. The growth regulators were applied in form of foliar spray, once at 30 days after planting (DAS) seedlings and again after 30days of first application. Plants sprayed with distilled water served as control. The results of the study revealed that application of NAA at 50ppm significantly reduced plant height $(28.33,30.13,30.53,36.33 \& 43.76 \mathrm{~cm})$ number of leaves (364.33) per plant. However, number of branches per plant were significantly improved due to application of NAA 25ppm (19.33) \& NAA100ppm (18.66) without showing significant variation from each other. Besides significant delay in flower bud initiation (20.66 days). Although application of NAA at $25 \mathrm{ppm} \&$ $100 \mathrm{ppm}$ significantly increased the number of flowers $(18.80 \& 17.96$ nos respectively) per plant, the size of flowers was significantly increased $(5.86 \mathrm{~cm} \&$ $5.06 \mathrm{~cm}$ dia respectively) under these treatments as compared to control.

\section{Introduction}

The plant Vinca rosea Linn (periwinkle) is an apocynaceous native to Europe, North West Africa and South West Asia. The plants are hardy and it can be grown in any type of soil. They are propagated from seeds or stem, including tip cutting. Ever-blooming, pubescent herb or sub-shrub. In India, the fresh flowers of Vinca are valued and used as loose flowers for religious and some medicinal property. Which has been shown to be a source of many alkaloids. There are 86 alkaloids extracted from the Vinca genus Manfred (Hesse, 2002). The chemotherapy agent alkaloid vincristine is extracted from Vinca rosea/Catharanthus roseus L. and is used to treat some leukemia's, lymphomas and childhood cancers as well as several other types of cancer and non-cancerous conditions 
vinblastine is also a chemical alkaloid analogue of vincristine and is also to treat various forms of cancer. PGRs are chemicals that modify the natural hormonal activity that controls plants growth and development. The key uses of plant growth regulators in ornamental horticulture and floriculture include regulation of plant height, profusion of branching, propagation through cutting, control of flowering, enhancing stress tolerance, increasing postharvest longevity during shipping storing and marketing, besides increasing the display of flowers and potted plants.

The objectives of this study were to study the effect of growth promoters (NAA) on plant growth of Vinca rosea. And to study the effect of growth promoters (NAA) on flowering of of Vinca rosea. Also to study the effect of growth promoters (NAA) on yield of Vinca rosea.

\section{Materials and Methods}

The present experiment was conducted in the Department of Floriculture and Landscaping, College of Agriculture, Orissa University of Agriculture and Technology, Bhubaneswar during the year 2015-16. Variety name Catharanthus caramel. Disease free healthy seeds were sown in the pots for seedling. The 25 days old seedlings were taken for field transplanting, after transplanting the plants were pressed gently and given light irrigation. Planting was done on the $2^{\text {nd }}$ May, 2015. Plot with dimension $80 \mathrm{X} 100 \mathrm{~cm}^{2}$ were prepared at a spacing of $40 \times 20 \mathrm{~cm}$. Plant growth regulators each at three concentrations $v i z$, NAA (25, 50 and 100ppm) and control (plants sprayed with distilled water) were allocated in randomized block design with three replication with ten plants per replication.. The growth regulators were applied in form of foliar spray, once at 30 days after planting (DAS) seedlings \& again after 30days of first application. Cultural operations like hoeing was manually taken at 30 days interval till the crop in the field. Weeding was done at monthly interval. The experimental plot was kept weed free by manual weeding till the crop in the field were followed as per standard cultural practices. Data on different growth, flowering and yield parameters were recorded on five randomly taken competitive plants for all the observations, i.e. plant height, number of functional leaves per plant, leaf area per plant, number of branches per plant and numbers of plant standing in plot were recorded at 30 days intervals from planting to flower buds. Number of flowers per plant and weight of flowers.

\section{Results and Discussion}

The results obtained from the present investigation as well relevant discussion have been summarized under following heads :

\section{Growth characters}

The data on plant height is presented in (Table $1 \mathrm{a}, \mathrm{b})$. A perusal of data in Table 1a shows that maximum plant height was recorded in Increase in plant height as a result of application of NAA has also been reported by Pal et al., (1980) slightly promoted the shoot length in Jasminum sambac var. Khoya. In J. auriculatum, NAA appreciably reduced the plant growth. In J. sambac the number of branches was increased due to NAA applications. Application of NAA at 50 and $100 \mathrm{ppm}$ recorded lowest length of primary lateral shoot in Jasminum multiflorum (Muruli, 1984). Similar report was observed with NAA at 100 and 200ppm in Jasminum sambac (Gowda, 1988).

Zaghloul et al., (1988) and (1989) studied the effects of 2 growth regulators on the rooting of jasmine cuttings. Cuttings of about $20 \mathrm{~cm}$ from the middle portion of the plant were 
dipped for $2 \mathrm{~h}$ in naphthalene acetic acid (NAA) at 0 (control), 500, 750 and 1000ppm or in kinetin at $0,50,75$ and 1000ppm, and in combinations of NAA and kinetin. All treatments increased the rooting. This experiment was conducted for the optimization of auxin [indole butyric acid (IBA) and naphthalene acetic acid (NAA)] required for the regeneration of Marigold. By dipping the cuttings in higher concentration of NAA showed the maximum increase in roots per plant (123.2) and root size (6.8). Gowda et $a l$. , (1990) reported that increased number of laterals, decreased shoot length, number and size of leaves jasmine. The treatment with NAA, GA and IBA together enhanced the vegetative growth and dry yield in Gloriosa superba (Mamtha et al., 1993). Singh et al., (1995) showed different effects of different growth hormones on plant height. $\mathrm{GA}_{3}$ and NAA both increased the plant height at 150 to $300 \mathrm{ppm}$, while higher level of $\mathrm{GA}_{3}$ and NAA (450 ppm) significantly depressed the plant height. The hormone treated plants showed early flowering than the control. Marked increase in flower yield due to increased in NAA application in jasmine was reported by Pal et al., (1980). Bhattacharjee, (1983) reported that NAA at $10 \mathrm{ppm}$ induced early initiation of flower and reduced corolla tube length and obtained largest flower diameter. Muruli (1984) reported that the application of NAA @ 50 and 100 ppm recorded lowest length of primary lateral shoot in Jasminum multiflorum. Similar report was observed by Gowda, (1988) with NAA @ 100 and 200ppm in Jasminum sambac.

Farooqi et al., (1993) reported that the three concentration of NAA 100, 300 and 400 ppm are significantly different from control for flower size and there is no difference between control and 200 ppm concentration of NAA. By dipping the seedling of Marigold in NAA maximum leaf size (3.20) was recorded at 200 ppm concentration, while minimum leaf size was observed at $400 \mathrm{ppm}$. Increased in leaves per plant were observed with increase in NAA concentration. Maximum plant height (7.80) was recorded at 100 and 200 ppm NAA concentration while minimum value was (5.0) at $300 \mathrm{ppm}$ concentration. By dipping the seedling in higher concentration of NAA showed the maximum increase in roots per plant (123.2) and root size (6.8). $300 \mathrm{ppm}$ showed maximum value for non-bloom flower and $200 \mathrm{ppm}$ showed the minimum value (3.2).

Table.1 The effect of plant growth regulators on the vegetative growth parameters of Vinca rosea

\begin{tabular}{|c|c|c|c|c|c|c|c|c|c|c|}
\hline $\begin{array}{l}\text { Treat } \\
\text { ments }\end{array}$ & Concentration & $\begin{array}{l}\text { plant } \\
\text { height } \\
\text { (cm) }\end{array}$ & $\begin{array}{l}\text { Number } \\
\text { of } \\
\text { branches } \\
\text { per plant }\end{array}$ & $\begin{array}{l}\text { Number } \\
\text { of leaves/ } \\
\text { Plant }\end{array}$ & $\begin{array}{l}\text { Girth of } \\
\text { plant } \\
\text { (cm) }\end{array}$ & $\begin{array}{l}\text { Leaf } \\
\text { length } \\
\text { (cm) }\end{array}$ & $\begin{array}{l}\text { Leaf } \\
\text { width } \\
\text { (cm) }\end{array}$ & $\begin{array}{l}\text { Leaf } \\
\text { Area } \\
\left(\mathrm{cm}^{2}\right)\end{array}$ & $\begin{array}{l}\text { Fresh } \\
\text { weight } \\
\text { of } \\
\text { plant } \\
\text { (g) }\end{array}$ & $\begin{array}{l}\text { Dry } \\
\text { weight } \\
\text { of } \\
\text { plant } \\
\text { (g) }\end{array}$ \\
\hline & & $\begin{array}{c}150 \\
\text { DAP }\end{array}$ & $\begin{array}{c}150 \\
\text { DAP }\end{array}$ & $\begin{array}{c}150 \\
\text { DAP }\end{array}$ & $\begin{array}{c}150 \\
\text { DAP }\end{array}$ & $\begin{array}{c}150 \\
\text { DAP }\end{array}$ & $\begin{array}{c}150 \\
\text { DAP }\end{array}$ & $\begin{array}{c}150 \\
\text { DAP }\end{array}$ & $\begin{array}{c}\text { 150 } \\
\text { DAP }\end{array}$ & $\begin{array}{c}150 \\
\text { DAP }\end{array}$ \\
\hline $\mathbf{T}_{1}$ & C- water Spray & 32.93 & 17.33 & 322.33 & 2.43 & 4.23 & 2.23 & 9.53 & 110.36 & 32.91 \\
\hline $\mathbf{T}_{2}$ & NAA 25ppm & 45.13 & 18.66 & 377.66 & 2.63 & 5.83 & 2.33 & 13.06 & 168.1 & 43.12 \\
\hline $\mathbf{T}_{\mathbf{3}}$ & NAA 50ppm & 43.76 & 17.66 & 364.33 & 2.66 & 5.66 & 2.23 & 12.44 & 166.21 & 42.04 \\
\hline $\mathbf{T}_{4}$ & NAA 100ppm & 39.93 & 17.66 & 347.33 & 2.53 & 5.16 & 2.03 & 11.71 & 164.06 & 41.18 \\
\hline
\end{tabular}


Table.2 The effect of plant growth regulators on the flowering and yield parameters of Vinca rosea

\begin{tabular}{|c|c|c|c|c|c|c|c|c|c|}
\hline $\begin{array}{l}\text { Treatm } \\
\text { ents }\end{array}$ & Concentration & $\begin{array}{l}\text { Days to flower } \\
\text { bud initiation to } \\
\text { flower opening } \\
\text { (days) }\end{array}$ & $\begin{array}{l}\text { Days to } \\
\text { flower } \\
\text { opening } \\
\text { (days) }\end{array}$ & $\begin{array}{c}\text { Durati } \\
\text { on of } \\
\text { floweri } \\
\text { ng } \\
\text { (days) }\end{array}$ & $\begin{array}{l}\text { Flower } \\
\text { size } \\
(\mathbf{c m})\end{array}$ & $\begin{array}{c}\text { Numbe } \\
r \text { of } \\
\text { flowers/ } \\
\text { plant }\end{array}$ & $\begin{array}{l}\text { Weigh } \\
t \text { of } \\
\text { single } \\
\text { flower } \\
\text { (g) }\end{array}$ & $\begin{array}{l}\text { Yield of } \\
\text { flowers/ } \\
\text { plant (g) }\end{array}$ & $\begin{array}{l}\text { Yield of } \\
\text { flowers } \\
\text { (kg/ha) }\end{array}$ \\
\hline & & $\begin{array}{c}150 \\
\text { DAP }\end{array}$ & $\begin{array}{c}150 \\
\text { DAP }\end{array}$ & $\begin{array}{c}150 \\
\text { DAP }\end{array}$ & $\begin{array}{c}150 \\
\text { DAP }\end{array}$ & $\begin{array}{c}150 \\
\text { DAP }\end{array}$ & $\begin{array}{c}150 \\
\text { DAP }\end{array}$ & $\begin{array}{c}150 \\
\text { DAP }\end{array}$ & $\begin{array}{c}150 \\
\text { DAP }\end{array}$ \\
\hline $\mathbf{T}_{1}$ & C-water Spray & 22.33 & 7.66 & 4.33 & 3.96 & 14.33 & 0.15 & 2.15 & 21.50 \\
\hline $\mathbf{T}_{2}$ & NAA 25ppm & 17.66 & 5.33 & 9.33 & 5.86 & 18.80 & 0.17 & 3.58 & 35.80 \\
\hline $\mathbf{T}_{3}$ & NAA 50ppm & 19.66 & 4.66 & 9.16 & 4.96 & 17.13 & 0.20 & 3.42 & 34.26 \\
\hline \multirow[t]{2}{*}{$\mathbf{T}_{4}$} & NAA 100ppm & 20.66 & 6.66 & 9.03 & 5.06 & 17.96 & 0.22 & 4.39 & 43.93 \\
\hline & CD (5\%) & $\mathbf{S}$ & S & $\mathbf{S}$ & $\mathbf{S}$ & $\mathbf{S}$ & $\mathbf{S}$ & $\mathbf{S}$ & $\mathbf{S}$ \\
\hline
\end{tabular}

Fig.1 Effect of NAA on Catharanthus roseus plant growth (Morphological characters of plants)

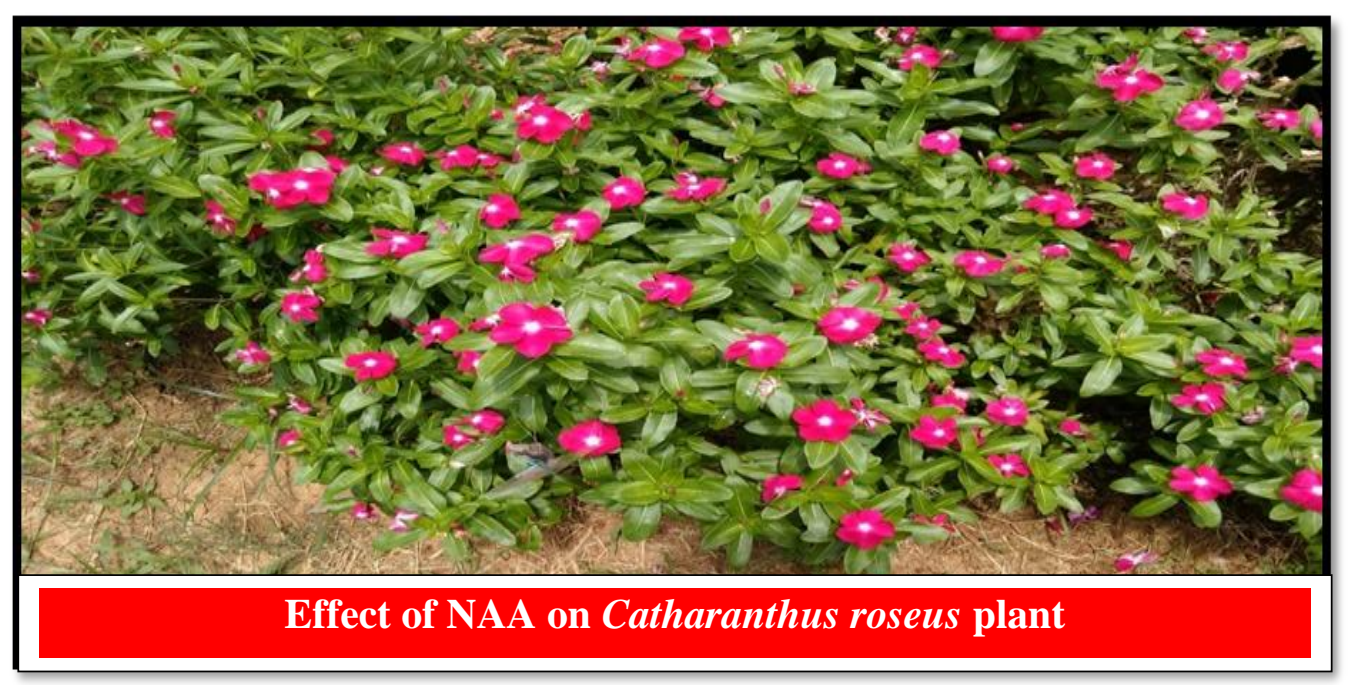

Fig.2 The effect of plant growth regulators on the vegetative growth parameters of Vinca rosea

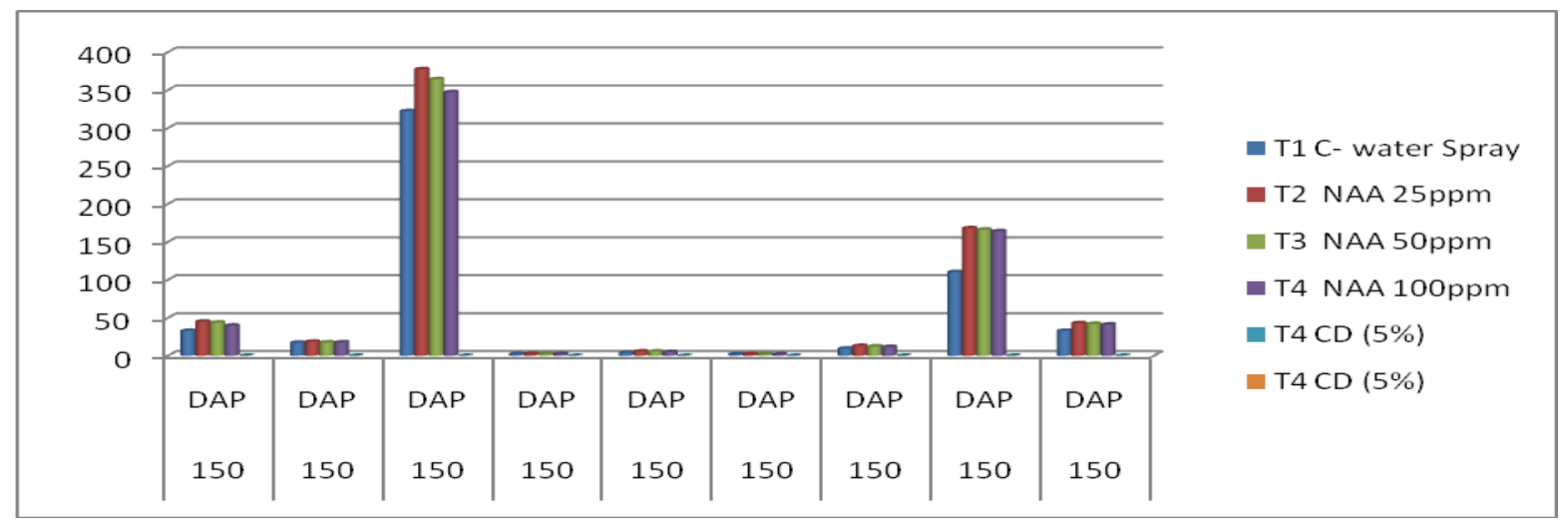


Fig.3 Effect of NAA on flower size and number of flowers/plant on Catharanthus roseus $L$.
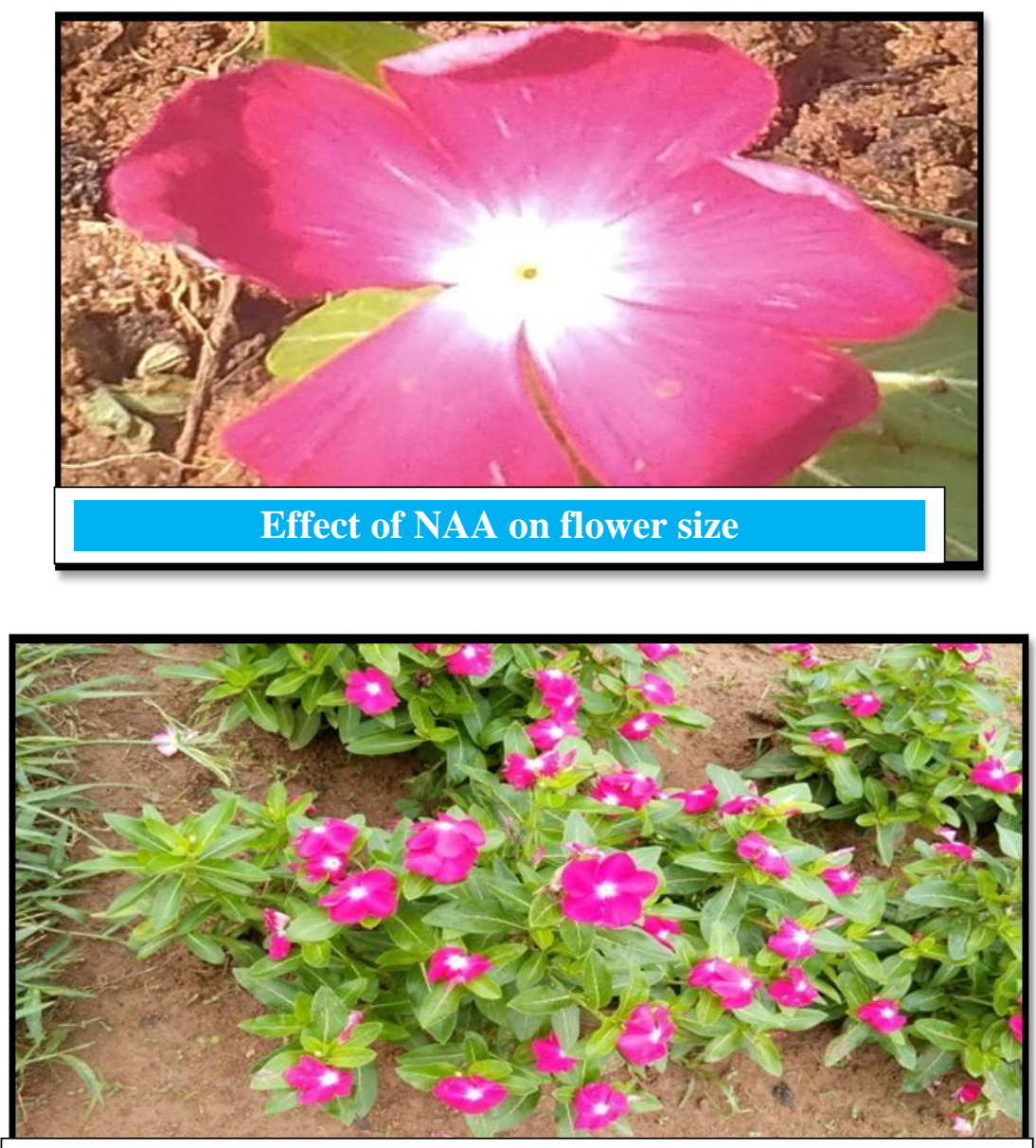

Effect of NAA during number of flowers/plant

Fig.4 The effect of plant growth regulators on the flowering and yield parameters of Vinca rosea

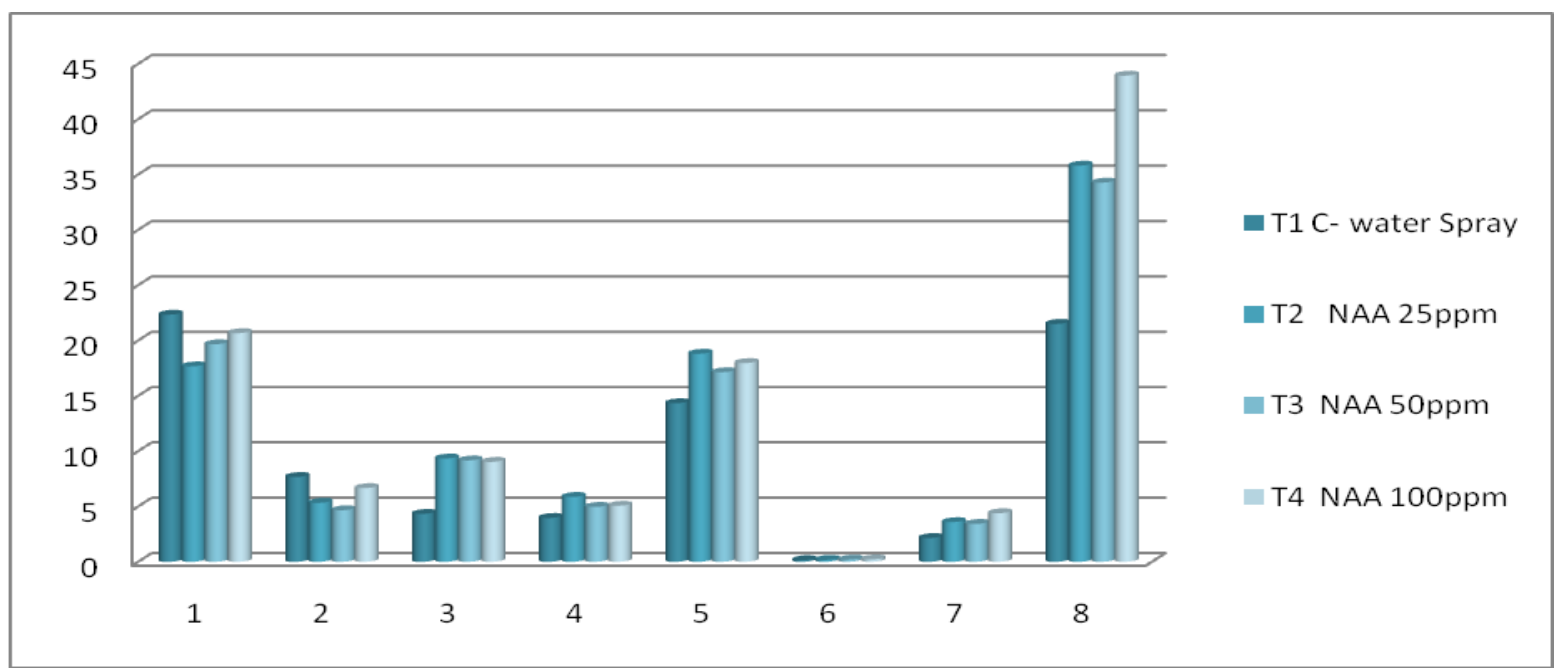


Alpha- Naphthalene Acetic Acid (NAA) $25 \mathrm{ppm}$ greatly enhanced the plant height, $100 \mathrm{ppm}$ greatly enhanced the number of branches/plant and also number of leaves/plant. The plant height was recorded at different intervals of $30,60,90,120 \& 150$ DAP $(35.33 \mathrm{~cm}, 36.26 \mathrm{~cm}, 37.03 \mathrm{~cm}, 42.76 \mathrm{~cm}$ $\& 45.13 \mathrm{~cm}$ ) highest number of branches/plant was recorded at different intervals of 30,60 , 90, 120 \& 150 DAP $(15.33,16.66,17.33$, $17.66 \& 18.66)$ respectively. Highest numbers of leaves were also registered (312.66, $321.66,332.33,337.66 \& 377.66)$. Increase in leaf length, width and leaf areas noted in NAA 25pm treated plants. AlphaNaphthalene Acetic Acid at 25ppm gave highest length of leaves $(5.83 \mathrm{~cm})$ and width of leaf $(2.33 \mathrm{~cm})$ which was superior to all the treatments experimented. Maximum leaf area of $(13.06 \mathrm{~cm} 2)$ was recorded with NAA $25 \mathrm{ppm}$.

\section{Flowering characters}

A perusal of data in Table $b$ shows that maximum flowering and yield NAA $25,50 \&$ $100 \mathrm{ppm}$ took (5.33, $4.66 \&$ 6.66) mean number of days to flower bud initiation to $1 \mathrm{st}$ flower opening. Whereas untreated plants took only 7.66 days. NAA $25,50 \& 100 \mathrm{ppm}$ mean yield of flowers $\mathrm{kg} / \mathrm{ha}$ was recorded $(35.80,34.26 \& 43.93)$.

\section{Yield characters}

The results of the study revealed that application of NAA at $25 \mathrm{ppm}$ recorded significantly higher plant height (35.33, $36.26,37.03,42.76$ and $45.13 \mathrm{~cm})$ number of leaves per plant (377.66 nos) at 150 DAS as compared to control which recorded 162.33, 180.66, 228.66, 293.33 and 322.33 nos respectively. Although there was improvement in number of flowers, flower size and duration of flowers under this treatment as compared to control, the difference was not significant. On the other application of at NAA $100 \mathrm{ppm}$ significantly reduced the time taken for flower bud initiation (20.66days) and days to $1 \mathrm{st}$ flowering from the date of bud initiation (6.66days) as compared to control which took 22.33 and 7.66 days respectively for the same.

From the study it could be concluded that the effect of NAA on growth, flowering and yield of Vinca rosea showed best response on applying $25 \mathrm{ppm}$ foliar spray on plants, thus it could be concluded that the plants of Vinca rosea will show best growth, flowering and yield response under application of $25 \mathrm{ppm}$ NAA foliar spray.

\section{Acknowledgement}

The research facility support as research lab, filed etc. to department of floriculture and landscaping from OUAT, Bhubaneswar is duely acknowledged.

\section{References}

Farooqui A. A. (1993). Effect of NAA on growth and flower yield. Flower size of marigold (Tagetes erecta L.) .Asian Journal .Horticulture, 6 (2):406 - 411.

Farooqi, A. A. (1993). Effect of growth regulators on growth, flowering and composition of gundumallige Jasminum Sambac. Proceedings of $4^{\text {th }}$ International Conference of Essential Oils, Fragrance and flowers, 3: 105112.

Girwani, A., Babu, R. S. and Chandrasekhar, R. (1987).Response of marigold (Tagetes erecta) to growth regulators and zinc. Indian Journal Agriculture. Science, 60 (3): 220 - 229.

Gianfagna and Merritt (2000).Effect of growth regulators on number of flowers and plant height of Aquilegia x hybrida. Plant Science (4) $121-123$. 
Gowda (1988).Effect of growth regulators on leaf growth of Jasminum sambac. Indian Journal Agriculture Science, 66.

Hesse RS. 2002. There are 86 alkaloids extracted from the Vinca genus Manfred and vincristine alkaloid extracted from Vinca rosea, Plant Science (6).

Mamtha, (1993). Effect of NAA enhanced the vegetative growth and yield in Gloriosa superba. Acta Horticulture Sinica.

Mukhopadhyaya, A., (1981), Response of carnation to spray application of NAA and Gibberellic acid. Haryana Journal of Horticultural Sciences, 19: 280-283.

Muradii B.M., Kawarth, V. J., Jane R. N. and Lale, S. R., (2003). Effect of plant growth regulators on growth, flowering and flower quality of jasmine. Orissa Journal of Horticulture, 31 (2): 33-36.

Nagarjuna, B., Reddy, V. P., Rao, M. K. and Reddy, E .N. (1988). Effect of growth regulators and potassium nitrate on growth and flowering and yield of chrysanthemum. South Indian Horticulture, 36 (3):136 - 140.

Nandre, U., O. Navandar Archana, and Watane D. (2009). Effect of growth regulators on growth, flowering and yield of China aster. The Asian Journal of Horticulture, June to November, 4(1): $50-51 T$

Nickell L. G. (1982). Plant growth regulators in agricultural uses Berlin: Springer, $191 \mathrm{p}$.

Pappiah, C. M. and Muthuswamy, S. (1978). Effect of some plant growth regulants on growth and flowering of Nerium. Indian Horticulture 22(3/4), 1974, 77 80.

Pappaiah, C. M. and Muthuswamy, S. (1978). Effect of growth retardants on growth, flowering in Jasmine. South Indian Horticulture, 23 (3\&4): 19- 21.

Panse, V. G. and Sukhatme, P. V. (1978).Statistical methods for agricultural works. II Edn. ICAR, New Delhi, India.

Sujatha, A., Nair, V. S. and Sharma, T. V. R. S. (2002). Effect of plant growth $b$ regulators on yield quality of gerbera under buy is; land conditions. Indian Journal Horticulture, 59 (1): 100 - 105.

.Sunitha, H.M., Hunje, R., Vyakaranahal, B . S. and Bablad, H .B. (2007) .Effect of pinching and growth regulators on plant growth, flowering and seed yield in African marigold (Tagetes erecta L.). J. Ornamental Hort. 1110 (2):91 -95.

\section{How to cite this article:}

Pooja Pahare and Das, J.N. 2020. Effect of Alpha-Naphthalene Acetic Acid [NAA] on Growth, Flowering and Yield of Vinca rosea cv. Catharanthus caramel. Int.J.Curr.Microbiol.App.Sci. 9(06): 1961-1967. doi: https://doi.org/10.20546/ijcmas.2020.906.242 